\title{
AIRPORTS AND THEIR INFRASTRUCTURE
}

UDC 656.71.003(045)

Tamara Oleshko

\section{FORMATION OF THE INFORMATION PORTRAIT OF THE AIRPORT}

\author{
National Aviation University \\ Kosmonavta Komarova avenue 1, 03680, Kyiv, Ukraine \\ E-mail: ti_oleshko@ukr.net
}

\begin{abstract}
The approach for categorizing type classes of the airports by kinds of non-aviation activity with the help of the simplified information matrices using the methods of clustering analysis was studied in the article.

Keywords: airport; non-aviation activities; the information matrix.
\end{abstract}

\section{Introduction}

In applied economic research of the airports' activity there is the scientific task of the airports' classification of a certain region for further estimation of its socio-economic efficiency. The solution of this task gives the person, who makes decisions, the possibility to justify the priority, completeness and structure of measures to improve the socio-economic efficiency of the typical airports in different regions.

\section{Research analysis and publications}

The issues regarding the efficient operation of the airports and its classifications according to the various criteria were studied by the following scientific men: U.F. Kulaev [2004], N.E. Polianska, V.M. Parii, S.L. Omelianenko, I.S. Golubev, O.V. Kostromina. The analysis of research results, published in the domestic and international scientific sources, makes possible to conclude about the insufficient research of this issue.

The purpose of the work is the analyze of approaches to categorizing the type classes of the airports by kinds of non-aviation activity with the help of simplified information matrices, using the methods of clustering analysis

\section{Main part}

To solve the issues of creating an information portrait of the airport it is necessary to give an adequate and complete definition of the term "comparability". It has been affirmed that values are being compared if there is some quantitative scale for measuring these information values.

In our case the comparability is provided in case of direction and the unit of measurement specified in the scale, and it is also an absolute minimum (zero) and maximum.
Thus, within the full information matrix of a class of the airport for each kind of non-aviation activity it is known which amount of information about belonging to the class it contains. This amount of information can not exceed a certain maximum value conditioned by the number of identification classes (Hartley measure) [Hartley 1959]:

$$
I_{\max }=\log _{2} W,
$$

where $W$ - the number of identification classes.

So, for the full information model of a cash flow of non-aviation activity of the airport or its functional subarea the comparability of individual amounts of information is also provided, because of usage of the ratio scale for them.

In a simplified version of the information matrix the variant of the Hamming distance [Hamming 1950], which considers only matches of existing criterias for codewords of the airport and the class, equals to:

$$
H^{i}=\sum_{j=1}^{n} F_{j}^{i} L_{j} ;
$$

where $F_{j}^{i}$ - a codeword - simplified matrix profile of non-aviation activity kinds of $j$ class:

$L_{j}=\left\{\begin{array}{l}1, \text { if there is kind of nonaviation activity, } \\ 0, \text { if there } i_{-} \text {no kind of nonaviation activity, }\end{array}\right.$
$L_{j}-$ a codeword - simplified matrix profile of non-aviation activity kinds of $j$ airport.

Let the length of a codeword (number of kinds of non-aviation activity) is $n$. The lengths of the codewords of the airport and classes are the same. Criterias can take values $\{0,1\}$. Than based on these conditions it comes up from the formula (1):

$$
0 \leq H^{i} \leq n \text {. }
$$


This means the full comparability of the similarity measure for the simplified information matrix of one airport or its functional subareas, and many classes of airports that follows from the definition of the ratio scale.

In the full information matrix the similarities measure of the airport with a class appears as follows:

$$
I^{i}=\frac{1}{\sigma_{I} \sigma_{L} n} \sum_{j=1}^{n}\left(F_{j}^{i}-\bar{F}^{i}\right)\left(L_{j}-\bar{L}\right),
$$

where $\sigma_{I}-$ standard deviation of the index of informative matrix according to the profile of the airport class:

$$
\sigma_{I}=\frac{1}{n-1} \sum_{j=1}^{n}\left(F_{j}^{i}-\bar{F}^{i}\right)^{2} ;
$$

$\sigma_{L}$ - standard deviation of the index of informative matrix according to profile of the recognized airport:

$$
\sigma_{L}=\frac{1}{n-1} \sum_{j=1}^{n}\left(L_{j}-\bar{L}\right)^{2} ;
$$

$\bar{F}^{i}$ - an average meaning for a codeword upon the profile of the airport class:

$$
\bar{F}^{i}=\frac{1}{n} \sum_{j=1}^{n} F_{j}^{i}
$$

$\bar{L}$ - an average meaning for a codeword upon the profile of the recognize airport:

$$
\bar{L}=\frac{1}{n} \sum_{j=1}^{n} L_{j} .
$$

Obviously, the value $I^{i}$ is normalized:

$$
0 \leq I^{i} \leq 1 \text {, }
$$

which proves the possibility of usage of the ratio scale and the full comparability of the similarity measure for the full information matrix of the one airport and many classes.

This means that it is possible to compare the similarity measures of this airport together with each from the classes and to rank classes in order of descending of the similarity with this airport.

Obviously, the value $I^{i}$, is calculated by the formula (2) for different airports and airport classes, is normalized by the formula (3), which allows to use the ratio scale and the full comparability of the similarity mesasures for the full information matrix of many airports and its many classes.

Similar arguments will be correct for comparison of profiles of airports' classes among themselves, which allows to use models of clustering analysis for the classification of the airports regarding kinds of non-aviation activity.
To justify the additivity of the integral criterion let's view the information matrices of the recognizable object and classes of airports recognition. These matrices are simplified, but quite adequate for solving the issue of additivity of the similarities measure of the airports and their classes.

An information matrix of the recognizable airport is a bit word, each bit of which corresponds to a certain kind of non-aviation activity. If a kind of non-aviation activity works at the airport, so the corresponding bit counts 1 , if no - 0 . A bit word with digits set to 1 , which correspond to the types of non-aviation activity of the recognizable airport, called by its codeword.

A simplified information recognition class model is a bit word, each bit of which corresponds to a certain type of non-aviation activity. The correspondence between bits' digits and kinds of non-aviation activity for classes is the same as for recognizable airports. If the factor is in the class, the corresponding bit is 1 , if not - then 0 . A bit word with digits set to 1 , that corresponds to the types of non-aviation activity, called by its codeword.

This recognition class model is simplified, because it adopted the following: all kinds of nonaviation activity have the same weight equal to $1-$ if they are in class, and 0 - if they are not in class, then like in the full information matrix of a class for each factor is known, which amount of information about belonging to this class it contains. This amount of information can not exceed a certain maximum value, due to the number of recognition classes (Hartley measure) [Hartley 1959]:

$$
I_{\text {max }}=\log _{2} N,
$$

where $N$ - the number of classes.

Thus, in a simplified information matrix different classes of recognition differ from each other only by sets of kinds of non-aviation activity, which they correspond to, that causes variability of estimates.

The recognition is that the codeword of the airport determines the most close to it in a certain sense codeword of the airport class. Herewith, the natural and the most easy similarity measure between a recognizable airport and the airport class is the Hamming distance between their codewords, i.e. the number of bits by which they differ from each other.

Let's consider the question of additivity of information amount in the integrated information criteria. There are only two ways of the integral criterion formation from the partial criteria [Chernorutskii 2004] - an additive and multiplicative. Let's view these options. 
Let's a codword consist of $N$ digits. Then adding of another digit, that shows available (1) or not (0) type of non-aviation activity, will lead to different results when the integral criterion is an additive and multiplicative function of individual amounts of information in types of non-aviation activity.

Examples of additive and multiplicative functions are given considering that

$$
I=f(n), f(1)=1, f(0)=0 .
$$

The additive function appears as follows:

$I=f\left(n_{1}, n_{2}, \ldots, n_{N}\right)=f\left(n_{1}\right)+f\left(n_{2}\right)+\ldots+f\left(n_{N}\right)$.

The multiplicative function:

$$
I=f\left(n_{1}, n_{2}, \ldots, n_{N}\right)=f\left(n_{1}\right) \times f\left(n_{2}\right) \times \ldots \times f\left(n_{N}\right) .
$$

Based on condition of presence of two kinds of non-aviation activity $f\left(n_{1}\right)=1$ and $f\left(n_{2}\right)=1$, according to (4) and (5) respectively have:

An additive criteria

$I=f\left(n_{1}, n_{2}\right)=1+1=2$;

A multiplicative criteria

$$
I=f\left(n_{1}, n_{2}\right)=1 \times 1=1 \text {. }
$$

Based on condition of absense of one of two kinds of non-aviation activity $f\left(n_{1}\right)=1$ and $f\left(n_{2}\right)=0$, according to (4) and (5) respectively have:

An additive criteria

$I=f\left(n_{1}, n_{2}\right)=1+0=1$;

A multiplicative criteria

$I=f\left(n_{1}, n_{2}\right)=1 \times 0=0$.

So, if a function is additive, then the adding one more digit will increase the amount of information in a codeword at 1 bit. If there is no an appropriate criteria, then it will not change this number. If the function is multiplicative, it will not change the amount of information in a codeword. If there is no an appropriate criteria, then it will make it equal to zero. The additive option of criterion is fully correspond to the classical concepts of the information nature, firstly justified by Hartley in 1928, confirmed by Shannon in 1948, and subsequently it has never been questioned [Hamming 1950].

An information matrix of kinds of non-aviation activity can be made for each typical airport. According to the destination of the airport, ground vantages, that have different level of activity of nonaviation activity, can be separated.

\section{Conclusions}

The information portrait of the airport is being forming basing on summarizing the information of the causative-consecutive diagram and the classification of kinds of non-aviation activity according to information criterion. With the help of simplified information matrices using the methods of clustering analysis it is conducting the definition of the typical classes of the airports by kinds of non-aviation activity.

\section{References}

Chernorutskii, I.G. 2004. Methods of optimization in the theory of management. Saint Petersburg. 256 p. (in Russian).

Hamming, R. 1950. Detection error and correction. Bell System Technical Journal. 29 (2): 147-160.

Hartley, R.L. 1959. Information transferring. Information theory and its supplements. Moscow. 350 p. (in Russian).

Kulaev, U.F. 2004. Economics of commercial aviation. Kyiv, Feniks. 667 p. (in Russian).

Received 11 November 2013.

\section{T.I. Олешко. Побудова інформаційного портрету аеропорту}

Національний авіаційний університет, просп. Космонавта Комарова, 1, Київ, Україна, 03680

E-mail: ti_oleshko@ukr.net

На основі узагальнення інформації причинно-наслідкової діаграми та класифікації видів неавіаційної діяльності за інформаційним критерієм побудовано інформаційний портрет аеропорту. За допомогою спрощених інформаційних матриць із застосуванням методів кластерного аналізу визначено типові класи аеропортів за видами неавіаційної діяльності.

Ключові слова: аеропорт; інформаційна матриця; неавіаційна діяльність.

\section{Т.И. Олешко. Построение информационного портрета аэропорта}

Национальный авиационный университет, просп. Космонавта Комарова, 1, Киев, Украина, 03680

E-mail: ti_oleshko@ukr.net

На основе обобщения информации причинно-следственной диаграммы и классификации видов неавиационной деятельности по информационному критерию построено информационный портрет аэропорта. С помощью упрощенных информационных матриц с применением методов кластерного анализа определены типичные классы ыэропортов по видам неавиционной деятельности.

Ключевые слова: аэропорт; информационная матрица; неавиационная деятельность.

Oleshko Tamara. Doctor of Engineering. Professor. Head of the Department of Economic Cybernetics, National Aviation University, Kyiv, Ukraine. Education: Kyiv Polytechnic Institute, Kyiv, Ukraine (1982).

Research area: modeling of complex systems. Publications: 155. E-mail: ti_oleshko@ukr.net 